\title{
Requirement of Nicotinic Acetylcholine Receptor Subunit $\beta 2$ in the Maintenance of Spiral Ganglion Neurons during Aging
}

\author{
Jianxin Bao, ${ }^{1}$ Debin Lei, ${ }^{1}$ Yafei Du, ${ }^{1}$ Kevin K. Ohlemiller, ${ }^{1}$ Arthur L. Beaudet, ${ }^{2}$ and Lorna W. Role ${ }^{3}$ \\ ${ }^{1}$ Department of Otolaryngology, Center for Aging, Washington University, St. Louis, Missouri 63110, ${ }^{2}$ Department of Molecular and Human Genetics, \\ Baylor College of Medicine, Houston, Texas 77030, and ${ }^{3}$ Center for Neurobiology and Behavior, Columbia University, New York, New York 10032
}

\begin{abstract}
Age-related hearing loss (presbycusis) is a major health concern for the elderly. Loss of spiral ganglion neurons (SGNs), the primary sensory relay of the auditory system, is associated consistently with presbycusis. The causative molecular events responsible for agerelated loss of SGNs are unknown. Recent reports directly link age-related neuronal loss in cerebral cortex with the loss of high-affinity nicotine acetylcholine receptors (nAChRs). In cochlea, cholinergic synapses are made by olivocochlear efferent fibers on the outer hair cells that express $\alpha 9$ nAChR subunits and on the peripheral projections of SGNs that express $\alpha 2, \alpha 4-7$, and $\beta 2-3 \mathrm{nAChR}$ subunits. A significantly decreased expression of the $\beta 2 \mathrm{nAChR}$ subunit in SGNs was found specifically in mice susceptible to presbycusis. Furthermore, mice lacking the $\beta 2 \mathrm{nAChR}$ subunit ( $\beta 2-/-)$, but not mice lacking the $\alpha 5 \mathrm{nAChR}$ subunit $(\alpha 5-/-)$, have dramatic hearing loss and significant reduction in the number of SGNs. Our findings clearly established a requirement for $\beta 2 \mathrm{nAChR}$ subunit in the maintenance of SGNs during aging.
\end{abstract}

Key words: presbycusis; aging; hearing loss; nicotinic receptors; spiral ganglion neurons; neurodegeneration

\section{Introduction}

Presbycusis is the third most prevalent condition of elderly persons (Morris et al., 1991; Seidman et al., 1999). Presbycusis is the result of the combined effects of intrinsic aging of the peripheral and central auditory systems (Pauler et al., 1986; Parham and Willott, 1988). Degeneration of spiral ganglion neurons (SGNs) during aging, with or without associated loss of hair cells, is common in humans and animals (Keithley and Feldman, 1979, 1982; Suzuka and Schuknecht, 1988; White et al., 2000). The pathogenesis of SGN degeneration is not well understood. One of the current hypotheses is that loss of SGNs in animals and in humans is secondary to loss of hair cells (Keithley and Croskrey, 1990). Numerous studies indicate that the target hair cells release trophic factors that support SGNs (Ernfors et al., 1995; Fritzsch et al., 1997; Hossain et al., 2002). After chemical or mechanical damage of hair cells, SGNs are rapidly lost, consistent with a target-dependent mechanism of SGN survival (Takeno et al., 1998). During the aging process, however, loss of SGNs may not arise strictly as a secondary degeneration after hair cell loss, because the extent of SGN death is much greater than that of hair cells (Ryals and Westbrook, 1988). Likewise, the localization of SGN loss is not always correlated with the location of hair cell loss (Keithley et al., 1989). Thus, the slow loss of SGNs during aging may involve hair cell-dependent and -independent mechanisms (Schuknecht and Gacek, 1993; Zimmermann et al., 1995; Ohlemiller and Gagnon, 2004).

This work is supported by National Institutes of Health Grants DC005145 (J.B.), NS29071 (L.W.R.), and DA-12661 (A.L.B.). We thank James Willott for analyzing auditory brainstem response data.

Correspondence should be address to Dr. Jianxin Bao, Department of Otolaryngology, Center for Aging, Washington University, Campus Box 8115, 660 South Euclid Avenue, St. Louis, M0 63110. E-mail: jbao@cid.wustl.edu. DOI:10.1523/JNEUROSCI.5277-04.2005

Copyright $\odot 2005$ Society for Neuroscience $\quad$ 0270-6474/05/253041-05\$15.00/0
Nicotinic acetylcholine receptors (nAChRs) are a multigene family of ligand-gated ion channels that participate in synaptic transmission (for review, see McGehee and Role, 1995; Changeux et al., 1998). Age-related changes of nAChR subunits expression in the CNS have been well documented (Birtsch et al., 1997; Rogers et al., 1998; Utsugisawa et al., 1999). For example, expression of $\alpha 3,4$, and 7 subunits are altered in certain regions of brain during aging, whereas the expression level of $\alpha 5$ subunit is unchanged (Tohgi et al., 1998; Ferrari et al., 1999; HellstromLindahl and Court, 2000). Interestingly, previous studies have shown the involvement of $\mathrm{nAChR}$ subunits in neuronal degeneration. Activation of $\alpha 7$-contaning nAChRs by low doses of nicotine results in neuronal apoptosis (Berger et al., 1998). Zoli et al. (1999) found age-related loss of hippocampal neurons in mice lacking the $\beta 2$ subunit. Here, we demonstrate that, in the peripheral nervous system (PNS), the expression level of the $\beta 2$ subunit is downregulated during aging in C57BL/6J mice. C57BL/6J strain is a mouse model for presbycusis (Henry and Chole, 1980) with the recessive age-related hearing loss (AHL) gene, which is most likely caused by a mutation in the cadherin 23 (Cdh23) gene $\left(\mathrm{Cdh} 23^{\text {ahl }}\right)$ (Noben-Trauth et al., 2003). Interestingly, the expression level of the $\beta 2$ subunit is increased in B6.CAST, which is a C57BL/6J congenic strain resistant to presbycusis with the wildtype allele of $C d h 23$ (Cdh23 ${ }^{\mathrm{CAST}}$ ). Furthermore, presbycusis appears in $\beta 2$ null mice under B6.CAST genetic background, and an accelerated age-related loss of SGNs is found in $\beta 2$ null mice but not in $\alpha 5$ null mice. Our findings indicate that $\beta 2 \mathrm{nAChR}$ subunit plays an important role in the maintenance of SGNs during aging.

\section{Materials and Methods}

Reverse transcriptase-PCR detection and real-time reverse transcriptase$P C R$. Two microliters of $70 \mu \mathrm{l}$ total RNA extracted from one spiral ganglion were used to measure semiquantitatively the change of each nAChR 
subunit. PCRs were performed for 35 cycles of $45 \mathrm{~s}$ at $94^{\circ} \mathrm{C}, 60 \mathrm{~s}$ at $52^{\circ} \mathrm{C}$, and $90 \mathrm{~s}$ at $72^{\circ} \mathrm{C}$ in a 25 $\mu 1$ reaction mixture containing $1 \times$ PCR buffer, $100 \mu \mathrm{M}$ dNTPs, $1 \mu \mathrm{M}$ each primer, and $1 \mathrm{U}$ of Taq polymerase (Boehringer Mannheim, Indianapolis, IN). Triplicates of each reaction were performed to assess experimental variance. PCR products were separated on 3\% NuSeive agarose gel (Flowgen, Wilford, UK), and the intensity of bands of the predicted size were measured by Image Pro Plus (Media Cybernetics, Silver Spring, MD) and normalized to synaptosomal-associated protein of $25 \mathrm{kDa}$ (snap-25) levels, similar to the procedures used in Devay et al. (1999). Samples prepared in parallel without reverse transcriptase (RT) were used as negative controls. Changes in the expression of the $\beta 2$ subunit during aging in both C57BL/6J and B6.CAST were examined by realtime RT-PCR methods using an ABI Prism 7700 Sequence Detection system (Applied Biosystems, Foster City, CA). PCR was performed with $20 \mu \mathrm{l}$ of reaction mixture containing $10 \mu \mathrm{l}$ of $2 \times$ SYBR Green PCR Master Mix (Applied Biosystems), $1 \mu \mathrm{l}$ of DNA template, and a 0.5 $\mu \mathrm{M}$ concentration of both forward and reverse primers. The thermal cycling conditions set for the ABI Prism 7700 Sequence Detector were the following: $50^{\circ} \mathrm{C}$ for $2 \mathrm{~min}$ and $95^{\circ} \mathrm{C}$ for $10 \mathrm{~min}$; then for the next 40 cycles, $95^{\circ} \mathrm{C}$ for $15 \mathrm{~s}$ and $60^{\circ} \mathrm{C}$ for $1 \mathrm{~min}$. The number of PCR cycles when the fluorescence intensity exceeded a predetermined threshold was measured during PCR. Quantification of the initial amount of template molecules relied on this number of PCR cycles, which is termed the cycle of threshold. The difference in the initial amount of total RNA between the samples was normalized in every assay using a housekeeping gene (glyceraldehyde-3-phosphate dehydrogenase) expression as an internal standard.

Protein assays. Similar to our previous work (Bao and Zervos, 1996), total proteins were isolated from SGNs of three cochleas (one each from three mice) at multiple stages of aging. The amount of total protein from each fraction was measured using a Bio-Rad (Hercules, CA) protein assay. Thirty micrograms of total protein were loaded and separated by SDS-PAGE and transferred to polyvinylidene difluoride membrane. Membranes were incubated with antibodies against nAChR subunit $\alpha 5$ or $\beta 2$ and processed with chemifluorescent reagents (ECL Western blotting detection reagents; Amersham Biosciences, Arlington Heights, IL).

Tissue preparation and histology. Hematoxylin and eosin staining: after the mice were killed, the cochleas were dissected, fixed, and decalcified in PBS solution containing 4\% paraformaldehyde and $0.25 \mathrm{M}$ EDTA for $2 \mathrm{~d}$. The cochleas were then embedded in $10 \%$ gum tragacanth (Sigma, St. Louis, MO) in liquid nitrogen. Eight micrometer mid-modiolar sections were cut. Sections were mounted and stained in Mayer's hematoxylin solution for $15 \mathrm{~min}$. Sections were then rinsed in warm water for $15 \mathrm{~min}$ and counterstained in aqueous Eosin Y solution for $30 \mathrm{~s}$. The slide was then dehydrated through $70-100 \%$ alcohol and mounted with resinous mounting medium. In every second section, the number of SGN nuclei at the right base region was counted under a $20 \times$ visual field using a computerized planimetry program of Image Pro Plus (Media Cybernetics). Because all sections were cut in the same orientation, it was possible to evaluate comparable regions across groups. The total number of SGNs was used for comparisons among different age groups by Mann-Whitney tests.

Auditory brainstem recoding. Animals were anesthetized $(80 \mathrm{mg} / \mathrm{kg}$ ketamine, $15 \mathrm{mg} / \mathrm{kg}$ xylazine, i.p.) and positioned dorsally in a custom head holder. Core temperature was maintained at $37.5^{\circ} \mathrm{C}$ using a thermostatically controlled heating pad in conjunction with a rectal probe. Platinum needle electrodes were inserted subcutaneously just behind the right ear (active), at the vertex (reference), and in the back (ground) Electrodes were led to a Grass P15 differential amplifier and then to a custom broadband amplifier. The signal was digitized at $30 \mathrm{kHz}$ using a Cambridge Electronic Design (Cambridge, UK) micro1401 in conjunction with Signal (Cambridge Electronic Design) and custom signal averaging software operating on a $120 \mathrm{MHz}$ Pentium personal computer (Intel, Santa Clara, CA). Sinewave stimuli generated by a HP3325A oscillator (Hewlett-Packard, Palo Alto, CA) were shaped by a custom electronic switch to $5 \mathrm{~ms}$ total duration, including $1 \mathrm{~ms}$ rise/fall times. The stimulus was amplified by a Crown D150A power amplifier and output to a KSN1020A piezo ceramic speaker (Motorola, Albuquerque, NM) located $7 \mathrm{~cm}$ directly lateral to the right ear, concentric with the external auditory meatus. Stimuli were presented freefield and calibrated using a B\&K Components (Buffalo, NY) 4135.25 inch microphone placed where the pinna would normally be. Tone-burst stimuli at each frequency and level were presented 1000 times at 20 per second. Threshold was taken to detect minimum sound pressure level required for a response.

\section{Results}

\section{Changes in the expression level of $\mathrm{nAChR}$ subunits in SGNs} during aging

We first determined whether there were changes in the expression of nAChR subunits in SGNs during aging. The levels of $\alpha 2-7$ and $\beta 2-4$ mRNAs were compared in 4- versus 8-month-old $\mathrm{C} 57 \mathrm{BL} / 6 \mathrm{~J}$ mice. In contrast to other sensory and autonomic ganglia, in which the $\alpha 3$ and/or $\beta 4$ mRNA are typically the predominant nAChR subunits expressed (Yeh et al., 2001), neither of these subunits was detected in RT-PCR assays of spiral ganglia at either age (data not shown). Instead, SGNs expressed $\alpha 2, \alpha 4, \alpha 5$, $\alpha 6, \alpha 7, \beta 2$, and $\beta 3 \mathrm{nAChR}$ mRNAs. Comparisons of spiral ganglia extirpated from 4-versus 8-month-old C57BL/6J mice revealed increased levels of $\alpha 4$ nAChR mRNA and significantly 
Table 1. Auditory brainstem response thresholds (sound pressure level in decibels) for $\alpha 5-/-, \beta 2-/-$, and their age (8 months of age)- and genetic-matched control mice

\begin{tabular}{llccccc}
\hline & $\begin{array}{l}\text { Mouse } \\
\text { number }\end{array}$ & \multicolumn{1}{c}{$4 \mathrm{kHz}$} & $8 \mathrm{kHz}$ & $12 \mathrm{kHz}$ & $16 \mathrm{kHz}$ & $24 \mathrm{kHz}$ \\
\hline$\alpha 5+/+$ & 6 & 21.7 & 20 & 21.7 & 18.3 & 40 \\
$\alpha 5-/-$ & 4 & 25 & 33.8 & 27.5 & 21.3 & 48.8 \\
$\beta 2+/+$ & 6 & 38 & 47 & 37 & 35 & 55 \\
$\beta 2-/-$ & 3 & $>100$ & $>100$ & $>100$ & 100 & $>100$ \\
\hline
\end{tabular}

The genetic background for $\alpha 5-1-$ mice and their $\alpha 5+/+$ control is (57BL/6J. The genetic background for $\beta 2-/-$ mice and their $\beta 2+/+$ control is on the mixed background of $129 / \mathrm{SvEv} \times(57 \mathrm{BL} / 6)$.

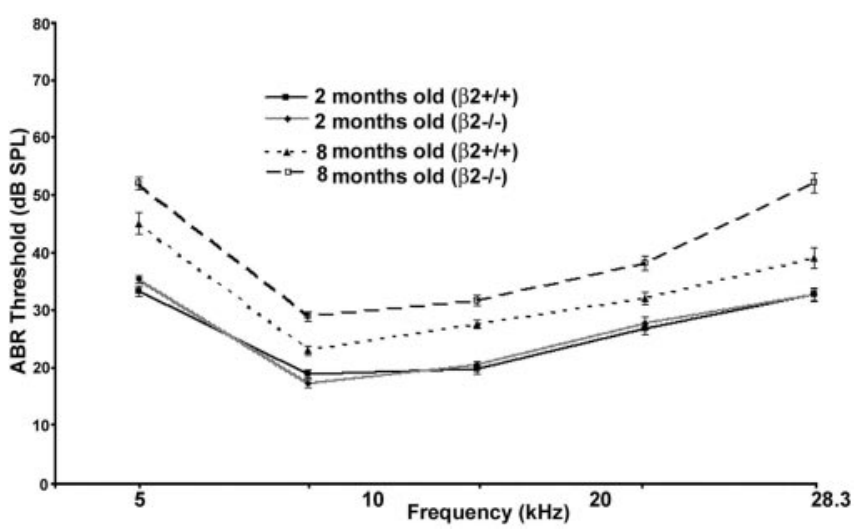

Figure 2. Mean $\pm S D$ auditory brainstem response (ABR) thresholds in young and old B6.CAST mice with or without the $\beta 2$ subunit. ABR thresholds were measured for 2 -month-old $\beta 2+/+(6$ male and 6 female) and $\beta 2-/-(4$ male and 8 female) mice and also for 8 -month-old wild-type AHL allele with $\beta 2+/+(5$ male and 5 female) and $\beta 2-/-(8$ male and 6 female) mice. Significant differences in 8 -month-old mice between $\beta 2+/+$ and $\beta 2-1-$ mice were found across all five frequencies tested (two-way ANOVA on ranks with Dunn multiple comparisons; $p<0.01$ ).

decreased levels of both $\alpha 5$ and $\beta 2$ nAChR mRNAs (Fig. $1 A, B$ ) when total neuronal mRNAs were kept constant. Western blot analysis suggested decreased levels of expression for both $\alpha 5$ and $\beta 2$ subunit proteins in aged mice (Fig. 1C). Semiquantitative RT-PCR confirmed significant changes in the expression of $\alpha 4$, $\alpha 5$, and $\beta 2$ subunits in SGNs during aging (Fig. $1 D$ ).

To test whether age-related decrease of $\beta 2$ subunit expression is associated specifically with presbycusis, age-related changes in the expression of $\beta 2$ subunit were compared further between C57BL/6J, which is a susceptible to age-related loss of SGNs, and B6.CAST, a congenic strain of C57BL/6J resistant to presbycusis. By real-time RT-PCR, a significant decrease in the expression level of the $\beta 2$ subunit in the 8-month-old C57BL/6J mouse group compared with the 4-month-old group was confirmed. In contrast, a statistically significant increase in the expression level of the $\beta 2$ subunit was found in 6B.CAST mice during aging (Fig. $1 E$ ). These results suggested a close association of a low $\beta 2$ level with age-related loss of SGNs.

Presbycusis in $\alpha 5-/-$ or $\beta 2-/-$ mice

To address whether the downregulation of $\alpha 5$ and $\beta 2 \mathrm{nAChRs}$ in SGNs during aging might be resulting in changes in auditory function, we measured hearing loss in 8-month-old $\alpha 5-1-$ or B2-/- mice (Xu et al., 1999; Zoli et al., 1999; Bansal et al., 2000). Assessment of the threshold of auditory brainstem responses to tone stimuli at $4,8,12,16$, and $24 \mathrm{kHz}$ revealed significant deficits in $\beta 2-/-$ mice, whereas $\alpha 5-/-$ mice appear normal compared with their age- and genetic background-matched controls. Hearing loss in $\beta 2-1-$ mice was dramatic: the hearing thresholds at

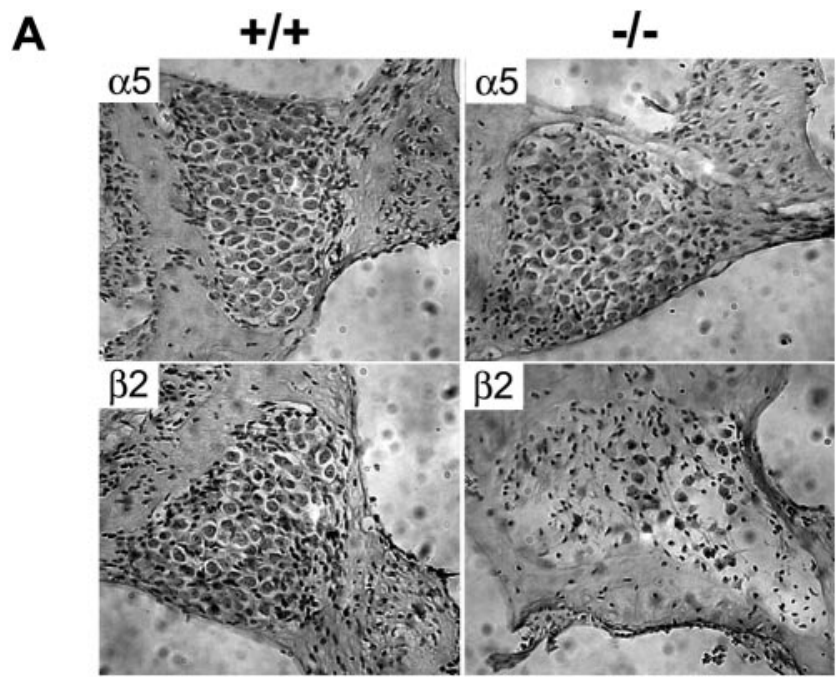

B

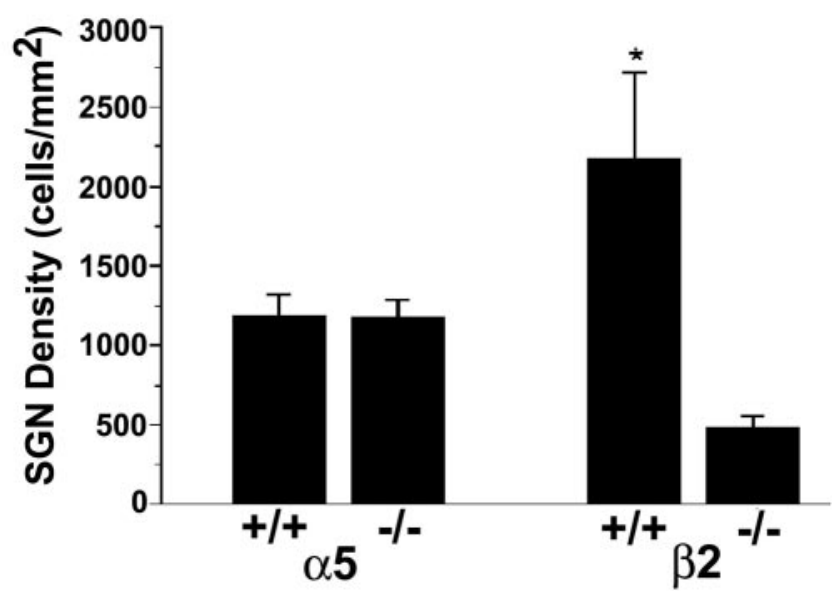

Figure 3. Histology of spiral ganglia from $\alpha 5$ or $\beta 2$ null mice. The top shows mid-modiolar sections of spiral ganglion from one 8-month-old mouse lacking $\alpha 5$ (right) and one 8-monthold $\alpha 5+/+$ control mouse (left) with the same genetic background $(\boldsymbol{A})$. The bottom consists of mid-modiolar sections of spiral ganglion from one 8-month-old mouse lacking $\beta 2$ (right) and one 8 -month-old $\beta 2+1+$ control mouse (left) with the same genetic background. Dramatic loss of SGNs can be observed in the section of spiral ganglia from 8-month-old mice lacking the $\beta 2$ subunit $(\boldsymbol{A})$. In $\boldsymbol{B}$, the right basal area of the spiral ganglion and the number of SGNs were quantified in every other section using Image Pro Plus (Media Cybernetics). Each group contains three 8-month-old mice. The density of SGNs in $\beta 2-1-$ mice was significantly decreased compared with genetic-matched controls $\left({ }^{*} p<0.01\right)$. Error bars represent SEM.

all five frequencies tested were between two and four times higher in $\beta 2-/-$ mice compared with their age- and genetic background-matched controls (Table 1). To eliminate possible contributions from the $A H L-/-$ genetic background, we crossed $\beta 2-/-$ mice into $A H L$ wild-type allele genetic background (B6.CAST). Hearing thresholds for both B6.CAST and $\beta 2-/-$ on B6.CAST genetic background were well with normal ranges at 2 months of age (Fig. 2). However, at 8 months of age, hearing was worse for $\beta 2-1-$ mice. Hearing threshold was also elevated for wild-type B6.CAST but was still much lower than that of C57BL/6J (data not shown). Thus, loss of $\beta 2-/-$ subunit clearly can accelerate presbycusis independent of the AHL allele.

Age-related hearing loss in $\beta 2-/-$ mice is causally related with dramatic loss of SGNs

To assess whether hearing loss in $\beta 2-/-$ mice might be causally related to the loss of SGNs, we studied the cell number of SGNs in 
8 -month-old $\beta 2-/-$ or $\alpha 5-/-$ mice. There is a dramatic loss in the number of SGNs in $\beta 2-/-$ but not $\alpha 5-/-$ mice at the basal region. Only a few SGNs are left in spiral ganglia from $\beta 2-/-$ mice (Fig. 3A). We further compared the density of SGNs in $\beta 2-/-$ or $\alpha 5-/-$ mice with their age- and genetic backgroundmatched controls (Fig. 3B). There are significantly fewer SGNs in $\beta 2-/-$ mice but not in $\alpha 5-/-$ mice. Thus, the hearing loss observed in aged $\beta 2-/-$ mice appears to derive from $\beta 2$-specific aspects of neuronal survival.

\section{Discussion}

Recent studies of neuronal AChRs revealed the possible role of nicotinic receptor subunits in normal aging and age-related neurodegeneration (Berger et al., 1998; Cordero-Erausquin et al., 2000; Ryan et al., 2001; Gotti and Clementi, 2004). Changes in the expression level of some $\mathrm{nAChR}$ subunits in aging or age-related neurodegenerative diseases have been found consistently in the CNS (Tohgi et al., 1998; Ferrari et al., 1999; Hellstrom-Lindahl, 2000). However, little is known about possible changes of nAChR subunits in the PNS during aging. The spiral ganglion provides an ideal system to study possible changes of nAChR subunits in the PNS during aging, because the neuronal population is $\sim 93 \%$ type 1 neurons and receives lateral olivocochlear cholinergic efferent innervation (Romand and Romand, 1987).

Expression of nAChR subunits in the cochlea has been examined previously in both mouse and rat (Housley et al., 1994; Drescher et al., 1995; Morley et al., 1998). Based on RT-PCR techniques, Drescher et al. (1995) demonstrated cochlear expression of $\alpha 2, \alpha 4-6$, and $\beta 2-3$ subunits in mouse cochlea, whereas $\alpha 3, \alpha 7$, and $\beta 4$ were not detectable. Using both RT-PCR and in situ hybridization methods, Morley et al. (1998) subsequently revealed cochlear presence of $\mathrm{nAChR}$ subunits $(\alpha 5-7$ and $\beta 2-3)$ and homogenous expressions of $\alpha 6, \alpha 7$, and $\beta 2$ among rat type I SGNs. Our examination of mouse SGNs reveals the expression of $\alpha 2, \alpha 4-7$, and $\beta 2-3$ in mouse SGNs consistent with previous studies of mouse cochlea, with the exception of $\alpha 7$ subunit (Drescher et al., 1995). The difference in the detection of $\alpha 7$ mRNA could have arisen from a difference in the RT-PCR condition, especially in the annealing temperature of $53-55^{\circ} \mathrm{C}$ used in the previous study (Drescher et al., 1995) and $65^{\circ} \mathrm{C}$ used in our study. There are no known studies on possible changes in the expression level of nAChR subunits in SGNs during aging. Our studies provide the first evidence showing age-related changes of $\alpha 4-5$ and $\beta 2$ expression level in SGNs.

Several recent studies suggest that, in addition to their traditional role in synaptic transmission, activation of $\mathrm{nAChR}$ subunits could protect neurons or lead to neuronal apoptosis (Berger et al., 1998; Pugh and Margiotta, 2000; Tohgi et al., 2000; Garrido et al., 2001). Activation of $\alpha 7$ subunit, for example, could promote cell survival or induce neuronal apoptosis (Berger et al., 1998; Tohgi et al., 2000; Dajas-Bailador and Wonnacott, 2004). This apparent paradoxical function may depend on the expression level of $\alpha 7$ subunit and subsequently functional interactions among various signal pathways triggered by activation of $\alpha 7$ subunit (Berger et al., 1998). Loss of $\beta 2$ subunit in vivo results in extensive age-related neurodegeneration in the CNS (Zoli et al., 1999). Age-related neuronal death in $\beta 2-/-$ mice could be explained by other factors such as an age-related elevation of stress hormone in these $\beta 2-/-$ mice. However, we found a decrease in the expression level of $\beta 2$ subunit correspondent to normal agerelated loss of SGNs in C57BL/6J but an increase in B6.CAST mice that is resistant to presbycusis. These data suggest a role of the $\beta 2$ subunit in age-related loss of SGNs. The specificity of the $\beta 2$ contribution was demonstrated further by the dramatic agerelated loss of SGNs found in the $\beta 2-1-$ mice but not in $\alpha 5-/-$ mice. It is unclear how a low level of $\beta 2$ subunit contributes to age-related loss of SGNs. A close association between neurotrophin-3 (NT-3) expression and survival of SGNs has been demonstrated during development (Farinas et al., 2001). It would be interesting to examine the interplay between low levels of $\beta 2$ subunit and expression of NT-3 and tyrosine receptor kinase $\mathrm{C}$ receptors in $\mathrm{SGN}$ s during aging.

In summary, we provide evidence consistent with the hypothesis that the $\beta 2 \mathrm{nAChR}$ subunit is required for the maintenance of SGNs during aging. Although previous studies documented changes in the number of nicotine binding sites and/or of subunit gene expression in the CNS with normal aging and specific pathological conditions, a causal relationship between changes in $\mathrm{nAChR}$ expression and neuronal degeneration is more difficult to establish (Role and Berg, 1996; Paterson and Nordberg, 2000). The current study, along with previous works, implicates the $\beta 2$ nAChR subunit in age-related loss of CNS and PNS neurons (Zoli et al., 1999). The prevention of age-related loss of SGNs by targeted restoration of $\beta 2$ in these neurons should reveal whether the $\beta 2 \mathrm{nAChR}$ subunit is both necessary and sufficient for neuronal survival with aging.

\section{References}

Bansal A, Singer JH, Hwang BJ, Xu W, Beaudet A, Feller MB (2000) Mice lacking specific nicotinic acetylcholine receptor subunits exhibit dramatically altered spontaneous activity patterns and reveal a limited role for retinal waves in forming $\mathrm{ON}$ and OFF circuits in the inner retina. J Neurosci 20:7672-7681.

Bao J, Zervos AS (1996) Isolation and characterization of Nmi, a novel partner of Myc proteins. Oncogene 12:2171-2176.

Berger F, Gage FH, Vijayaraghavan S (1998) Nicotinic receptor-induced apoptotic cell death of hippocampal progenitor cells. J Neurosci 18:6871-6881.

Birtsch C, Wevers A, Traber J, Maelicke A, Bloch W, Schroder H (1997) Expression of alpha 4-1 and alpha5 nicotinic cholinoceptor mRNA in the aging rat cerebral cortex. Neurobiol Aging 18:335-342.

Changeux JP, Bertrand D, Corringer PJ, Dehaene S, Edelstein S, Lena C, Le Novere N, Marubio L, Picciotto M, Zoli M (1998) Brain nicotinic receptors: structure and regulation role in learning and reinforcement. Brain Res Brain Res Rev 26:198-216.

Cordero-Erausquin M, Marubio LM, Klink R, Changeux JP (2000) Nicotinic receptor function: new perspectives from knockout mice. Trends Pharmacol Sci 21:211-217.

Dajas-Bailador F, Wonnacott S (2004) Nicotinic acetylcholine receptors and the regulation of neuronal signalling. Trends Pharmacol Sci 25:317-324.

Devay P, McGehee DS, Yu CR, Role LW (1999) Target-specific control of nicotinic receptor expression at developing interneuronal synapses in chick. Nat Neurosci 2:528-534.

Drescher DG, Khan KM, Green GE, Morley BJ, Beisel KW, Kaul H, Gordon D, Gupta AK, Drescher MJ, Barretto RL (1995) Analysis of nicotinic acetylcholine receptor subunits in the cochlea of the mouse. Comp Biochem Physiol C Pharmacol Toxicol Endocrinol 112:267-273.

Ernfors P, Kucera J, Lee KF, Loring J, Jaenisch R (1995) Studies on the physiological role of brain-derived neurotrophic factor and neurotrophin-3 in knockout mice. Int J Dev Biol 39:799-807.

Farinas I, Jones KR, Tessarollo L, Vigers AJ, Huang E, Kirstein M, Caprona DC, Coppola V, Backus C, Reichardt LF, Fritzsch B (2001) Spatial shaping of cochlear innervation by temporally regulated neurotrophin expression. J Neurosci 21:6170-6180.

Ferrari R, Pedrazzi P, Algeri S, Agnati LF, Zoli M (1999) Subunit and regionspecific decreases in nicotinic acetylcholine receptor mRNA in the aged rat brain. Neurobiol Aging 20:37-46.

Fritzsch B, Silos-Santiago I, Bianchi LM, Farinas I (1997) Effects of neurotrophin and neurotrophin receptor disruption on the afferent inner ear innervation. Semin Cell Dev Biol 8:277-284.

Garrido R, Mattson MP, Hennig B, Toborek M (2001) Nicotine protects against arachidonic-acid-induced caspase activation, cytochrome $\mathrm{c}$ re- 
lease and apoptosis of cultured spinal cord neurons. J Neurochem 76:1395-1403.

Gotti C, Clementi F (2004) Neuronal nicotinic receptors: from structure to pathology. Prog Neurobiol 74:363-396.

Hellstrom-Lindahl E, Court JA (2000) Nicotinic acetylcholine receptors during prenatal development and brain pathology in human aging. Behav Brain Res 113:159-168.

Henry KR, Chole RA (1980) Genotypic differences in behavioral, physiological and anatomical expressions of age-related hearing loss in the laboratory mouse. Audiology 9:369-383.

Hossain WA, Brumwell CL, Morest DK (2002) Sequential interactions of fibroblast growth factor-2, brain-derived neurotrophic factor, neurotrophin-3, and their receptors define critical periods in the development of cochlear ganglion cells. Exp Neurol 175:138-151.

Housley GD, Batcher S, Kraft M, Ryan AF (1994) Nicotinic acetylcholine receptor subunits expressed in rat cochlea detected by the polymerase chain reaction. Hear Res 75:47-53.

Keithley EM, Croskrey KL (1990) Spiral ganglion cell endings in the cochlear nucleus of young and old rats. Hear Res 49:169-177.

Keithley EM, Feldman ML (1979) Spinal ganglion cell counts in age-graded series of rat cochleas. J Comp Neurol 188:429-442.

Keithley EM, Feldman ML (1982) Hair cell counts in an age-graded series of rat cochleas. Hear Res 8:249-262.

Keithley EM, Ryan AF, Woolf NK (1989) Spiral ganglion cell density in young and old gerbils. Hear Res 38:125-133.

McGehee DS, Role LW (1995) Physiological diversity of nicotinic acetylcholine receptors expressed by vertebrate neurons. Annu Rev Physiol 57:521-546.

Morley BJ, Li HS, Hiel H, Drescher DG, Elgoyhen AB (1998) Identification of the subunits of the nicotinic cholinergic receptors in the rat cochlea using RT-PCR and in situ hybridization. Brain Res Mol Brain Res 53:78-87.

Morris JC, McKeel Jr DW, Storandt M, Rubin EH, Price JL, Grant EA, Ball MJ, Berg L (1991) Very mild Alzheimer's disease: informant-based clinical, psychometric, and pathologic distinction from normal aging. Neurology 41:469-478.

Noben-Trauth K, Zheng QY, Johnson KR (2003) Association of cadherin 23 with polygenic inheritance and genetic modification of sensorineural hearing loss. Nat Genet 35:21-23.

Ohlemiller KK, Gagnon PM (2004) Apical-to-basal gradients in age-related cochlear degeneration and their relationship to "primary" loss of cochlear neurons. J Comp Neurol 479:103-116.

Parham K, Willott JF (1988) Acoustic startle response in young and aging C57BL/6J and CBA/J mice. Behav Neurosci 102:881-886.

Paterson D, Nordberg A (2000) Neuronal nicotinic receptors in the human brain. Prog Neurobiol 61:75-111.

Pauler M, Schuknecht HF, Thornton AR (1986) Correlative studies of cochlear neuronal loss with speech discrimination and pure tone thresholds. Arch Otorhinolaryngol 243:200-206.

Pugh PC, Margiotta JF (2000) Nicotinic acetylcholine receptor agonists promote survival and reduce apoptosis of chick ciliary ganglion neurons. Mol Cell Neurosci 15:113-122.
Rogers SW, Gahring LC, Collins AC, Marks M (1998) Age-related changes in neuronal nicotinic acetylcholine receptor subunit $\alpha 4$ expression are modified by long-term nicotine administration. J Neurosci 18:4825-4832.

Role LW, Berg DK (1996) Nicotinic receptors in the development and modulation of CNS synapses. Neuron 16:1077-1085.

Romand MR, Romand R (1987) The ultrastructure of spiral ganglion cells in the mouse. Acta Otolaryngol 104:29-39.

Ryals BM, Westbrook EW (1988) Ganglion cell and hair cell loss in Coturnix quail associated with aging. Hear Res 36:1-8.

Ryan RE, Ross SA, Drago J, Loiacono RE (2001) Dose-related neuroprotective effects of chronic nicotine in 6-hydroxydopamine treated rats, and loss of neuroprotection in alpha4 nicotinic receptor subunit knockout mice. Br J Pharmacol 132:1650-1656.

Schuknecht HF, Gacek MR (1993) Cochlear pathology in presbycusis. Ann Otol Rhinol Laryngol 158:1-16.

Seidman MD, Quirk WS, Shirwany NA (1999) Mechanisms of alterations in the microcirculation of the cochlea. Ann NY Acad Sci 884:226-232.

Suzuka Y, Schuknecht HF (1988) Retrograde cochlear neuronal degeneration in human subjects. Acta Otolaryngol Suppl 450:1-20.

Takeno S, Wake M, Mount RJ, Harrison RV (1998) Degeneration of spiral ganglion cells in the chinchilla after inner hair cell loss induced by carboplatin. Audiol Neurootol 3:281-290.

Tohgi H, Utsugisawa K, Yoshimura M, Nagane Y, Mihara M (1998) Agerelated changes in nicotinic acetylcholine receptor subunits alpha4 and beta2 messenger RNA expression in postmortem human frontal cortex and hippocampus. Neurosci Lett 245:139-142.

Tohgi H, Utsugisawa K, Nagane Y (2000) Protective effect of nicotine through nicotinic acetylcholine receptor alpha7 on hypoxia-induced membrane disintegration and DNA fragmentation of cultured PC12 cells. Neurosci Lett 285:91-94.

Utsugisawa K, Nagane Y, Tohgi H, Yoshimura M, Ohba H, Genda Y (1999) Changes with aging and ischemia in nicotinic acetylcholine receptor subunit alpha7 mRNA expression in postmortem human frontal cortex and putamen. Neurosci Lett 270:145-148.

White JA, Burgess BJ, Hall RD, Nadol JB (2000) Pattern of degeneration of the spiral ganglion cell and its processes in the C57BL/6J mouse. Hear Res 141:12-18.

Xu W, Orr-Urtreger A, Nigro F, Gelber S, Sutcliffe CB, Armstrong D, Patrick JW, Role LW, Beaudet AL, De Biasi M (1999) Multiorgan autonomic dysfunction in mice lacking the $\beta 2$ and the $\beta 4$ subunits of neuronal nicotinic acetylcholine receptors. J Neurosci 19:9298-9305.

Yeh JJ, Yasuda RP, Davila-Garcia MI, Xiao Y, Ebert S, Gupta T, Kellar KJ, Wolfe BB (2001) Neuronal nicotinic acetylcholine receptor alpha3 subunit protein in rat brain and sympathetic ganglion measured using a subunit-specific antibody: regional and ontogenic expression. J Neurochem 77:336-346.

Zimmermann C, Burgess BJ, Nadol JB (1995) Patterns of degeneration in the human cochlear nerve. Hear Res 90:192-201.

Zoli M, Picciotto MR, Ferrari R, Cocchi D, Changeux JP (1999) Increased neurodegeneration during ageing in mice lacking high-affinity nicotine receptors. EMBO J 18:1235-1244. 